\title{
Bidespor i søpindsvin - hvem er synderen?
}

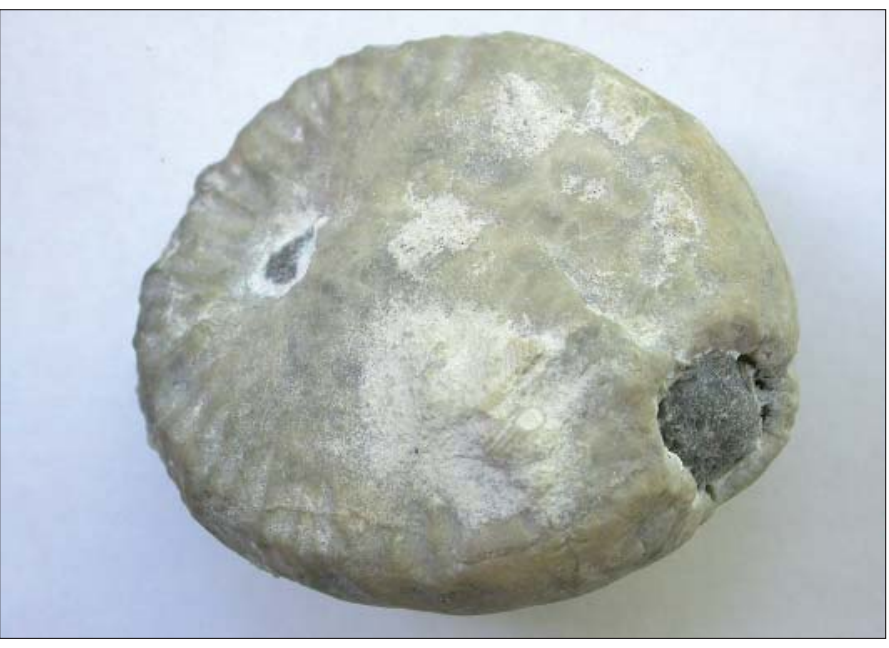

Søpindsvinet set fra bunden. Bemæerk bidemæerkerne rundt om dyrets gat. (Foto: Forfatteren)

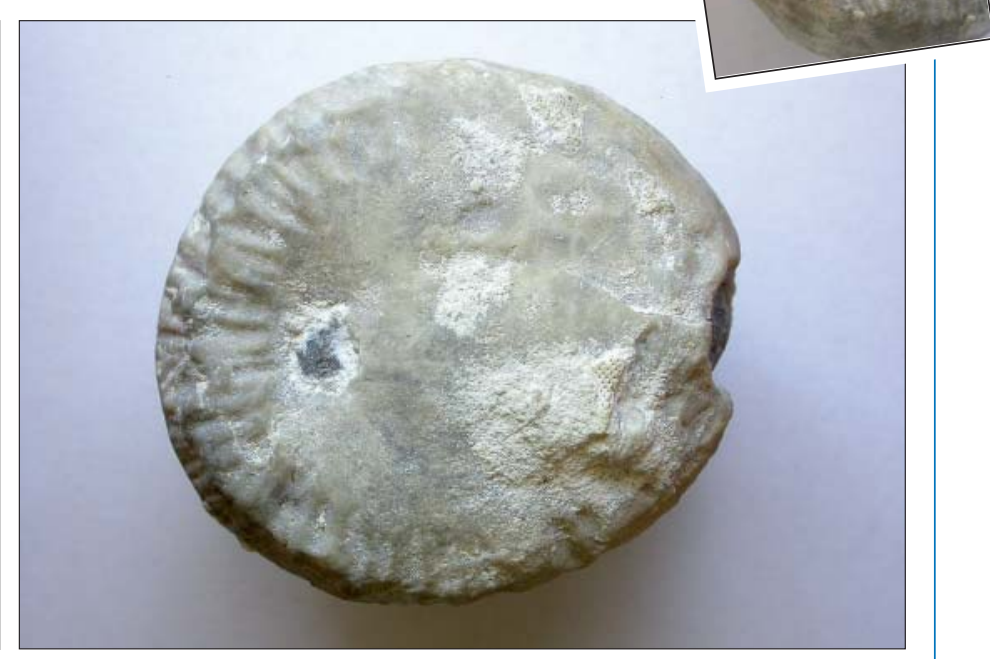

Søpindsvinet set fra bunden. Øverst ses en forstørrelse af bidemcerkerne langs kanten. (Fotos: Forfatteren)

\section{Af Henrik Madsen, Molermuseet}

Et søpindsvin med nogle fæle gnavemærker i skallen - hvem kan mon have gjort det?

For nylig var jeg på besøg hos Lulu og Vagner Nielsen, to fossilsamlere fra stenklubben S.A.F. i Næstved. Vi talte selvfølgelig også om fossiler, og samtalen kom ind på de danske søpindsvin. Lulu fortalte, at hun havde fundet et søpindsvin, som var blevet offer for kannibalisme. Hun havde fået fortalt, at de søpindsvin, der blev fundet i kalkgraven ved Hove med bidespor, var blevet spist, fordi der ikke var mad nok til alle søpindsvinene. Jeg blev lidt skeptisk og sagde, at det ville jeg godt se.

\section{Bidemærker langs kanten}

Da søpindsvinet, som er en Echninocorys obliqua på 3,5 x 4,2 cm, blev vist frem, var der slet ingen tvivl om, at der er tale om bidespor. Dog kunne jeg ikke med den viden, som jeg har om tandapparatet på søpindsvin, få det til at passe. Aristoteles lygte, som det hedder, har fem tænder og vil efter min mening lave nogle helt andre bidemærker.

Bidemærkerne er lavet langs skallens kant $i$ bunden på ca. $3 / 4$ af fossilet. Når søpindsvinet ses fra bunden med gattet vendt ind mod en selv, er sporerne startet midt på højre side. Der er $1 \mathrm{~cm}$ imellem bidesporernes yderpunkter, og i midten er der dannet en lille kam. Disse spor hælder for det meste lidt fremad mod uret, men ved munden er der arbejdet lidt hårdere på sagen. Sporerne er her tætte og lidt dybere. Den mere regelmæssige biden er fortsat videre rundt langs kanten, men tæt ved gattet er der $5 \mathrm{~mm}$ uden bidespor. Herefter er der blevet arbejdet hele vejen rundt om langs gattet, så hullet er blevet betydeligt større. Det måler 0,8 x 1,2 $\mathrm{cm}$, mens gattet normalt måler $0,3 \times 0,4 \mathrm{~cm}$.

Hvem der kunne være synderen, skulle der så ses nærmere på. I en tysk artikel af Max Giessler beskrives bidespor på en Echnicorys scutatus fundet i Kridt fra Senon. Disse fire huller og tre aflange ridser på siden var formentlig lavet af en rovfisk med kraftige spidse tænder, som menes at være en Enchodus. Det kunne ikke være den samme type fisk, som har bidt i det danske søpindsvin pga. bidemærkernes form.

\section{Synderen}

Der måtte være tale om en anden dyregruppe. Det kunne måske være en blæksprutte, som har et kraftigt næb, der minder om næbbet på en papegøje. Det kunne også være krebsdyr, som har spist søpindsvinet. Et forsøg på at rekonstruere sporerne blev gjort med kloen fra en almindelig strandkrabbe i modellervoks, og det viste sig, at sporene ligner ret godt. Hvis man tager i betragtning, at der tale om et krebsdyr, hvor kloen var anderledes, er der vist ikke andre muligheder, for at et andet dyr skulle kunne lave disse bidemærker.
Der kendes til snegle fra det danske oligocæne glimmerler, som er blevet bidt i og formentlig ædt af krabber. Fra det fossilrige eocæne Barton-ler i England er der fundet flere tilfælde, hvor man kan se, at snegle har overlevet angreb fra krabber, idet skallen er vokset videre - ar kan ses midt på sneglehuset. I det miocæne Gramler er der fundet mange muslinger og snegle, som er spist af Natica- rovsneglen. Sneglen laver et cirkulært lille hul, hvor den suger byttet ud af skallen. I det eocæne moler er der fundet makrelfisk med bytte i maven, og der er sågar fundet en smelt, hvor der stikker en strømsild ud af munden.

\section{Efterlysning}

Skulle der blandt GeologiskNyts læsere være nogle, som har kendskab til, eller som ejer søpindsvin med bidespor, vil forfatteren meget gerne kontaktes påmail@molermuseet. dk eller tlf. 97751716

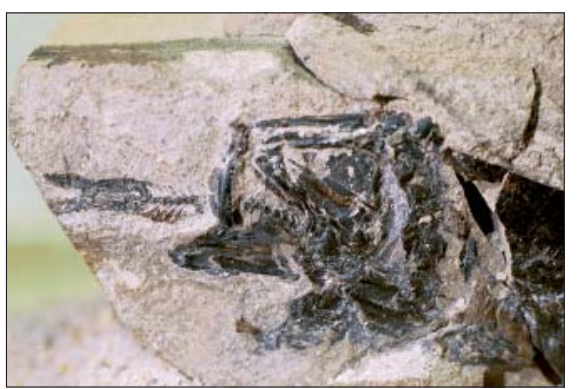

Forstenet smelt med strømsild i munden.

(Foto: Forfatteren) 